\title{
Chlamydia trachomatis detected in human placenta
} M Gencay, M Puolakkainen, T Wahlström, P Ämmälä, L Mannonen, A Vaheri,
M L Koskiniemi mia appeared in the adrenal glands and spleen. The mother had high IgG antibody titres (1:128) to $C$ trachomatis pooled immunotypes GFK and BED at the 13th week of gestation while IgM to $C$ trachomatis was negative when evaluated in a microimmunofluorescence test. Using an antibody screen against 16 microbes, the mother had a high serum IgG antibody level to herpes simplex virus (HSV) type 2, other antibody levels were unremarkable. Culture from a cervical specimen had been positive to $C$ trachomatis three years earlier. At that time the patient had been treated for 10 days with doxycycline. During the present pregnancy no cultures were performed.

\section{IN SITU HYBRIDISATION}

A digoxigenin labelled RNA probe was constructed from $C$ trachomatis $\mathrm{L}_{2} 7.5 \mathrm{~kb}$ plasmid (kindly donated by Dr S Larsen, Indiana University School of Medicine, Indiana, USA). ${ }^{6}$ Sections of paraffin embedded placental tissue, cut at $4 \mu \mathrm{m}$ were floated on to silane treated slides. The tissue sections were deparaffinised and rehydrated. For in situ hybridisation, the tissue sections were fixed in $4 \%$ paraformaldehyde and digested with proteinase $\mathrm{K}$. Tissue sections were immediately refixed in $4 \%$ paraformaldehyde and acetylated in triethanolamine $(\mathrm{pH} 8.0)$ containing acetic anhydride. After specimen dehydration through graded ethanols, they were prehybridised by adding hybridisation buffer $(2 \times$ saline sodium citrate (SSC), $50 \%$ deionised formamide, $1 \times$ Denhardt's, $500 \mu \mathrm{g} / \mathrm{ml}$ yeast tRNA, $0.1 \%$ Tween 20, 0.1\% CHAPS (Sigma, St Louis, Missouri, USA), $5 \mathrm{mM}$ ethylenediamine tetraacetic acid (EDTA), and $100 \mu \mathrm{g} / \mathrm{ml}$ heparin (Sigma). For hybridisation, $60 \mu \mathrm{l}$ of hybridisation mix containing $0.2 \mathrm{ng} / \mu \mathrm{l}$ of probe was placed on to the tissues. Coverslips were sealed with rubber cement, and the tissues were denatured at $80^{\circ} \mathrm{C}$ for 10 minutes and hybridised with the labelled probe at $37^{\circ} \mathrm{C}$ overnight. The post-hybridisation washes were performed under highly stringent conditions.

Controls included tissue sections with hybridisation solution without probe and tissue sections with hybridisation solution containing a non-specific probe prepared from the vector. To remove any unbound probe, sections were treated with RNase $(100 \mu \mathrm{g} / \mathrm{ml})$ at $37^{\circ} \mathrm{C}$. Following post-hybridisation washes, the hybridisation signal was detected according to the instructions of the DIG Nucleic Acid detection Kit (Boehringer Mannheim, Mannheim, Germany). All tissue sections were tested blindly.

\section{CASE HISTORY}

A stillbirth fetus was born to a 21 year old mother at the 36th week of gestation. The placenta was abrupted and a male fetus was delivered by caesarean section. At necropsy the fetus appeared normal. By microscopic examination, petechiae were observed in the lungs, pericardium, and thymus and hyperae- 

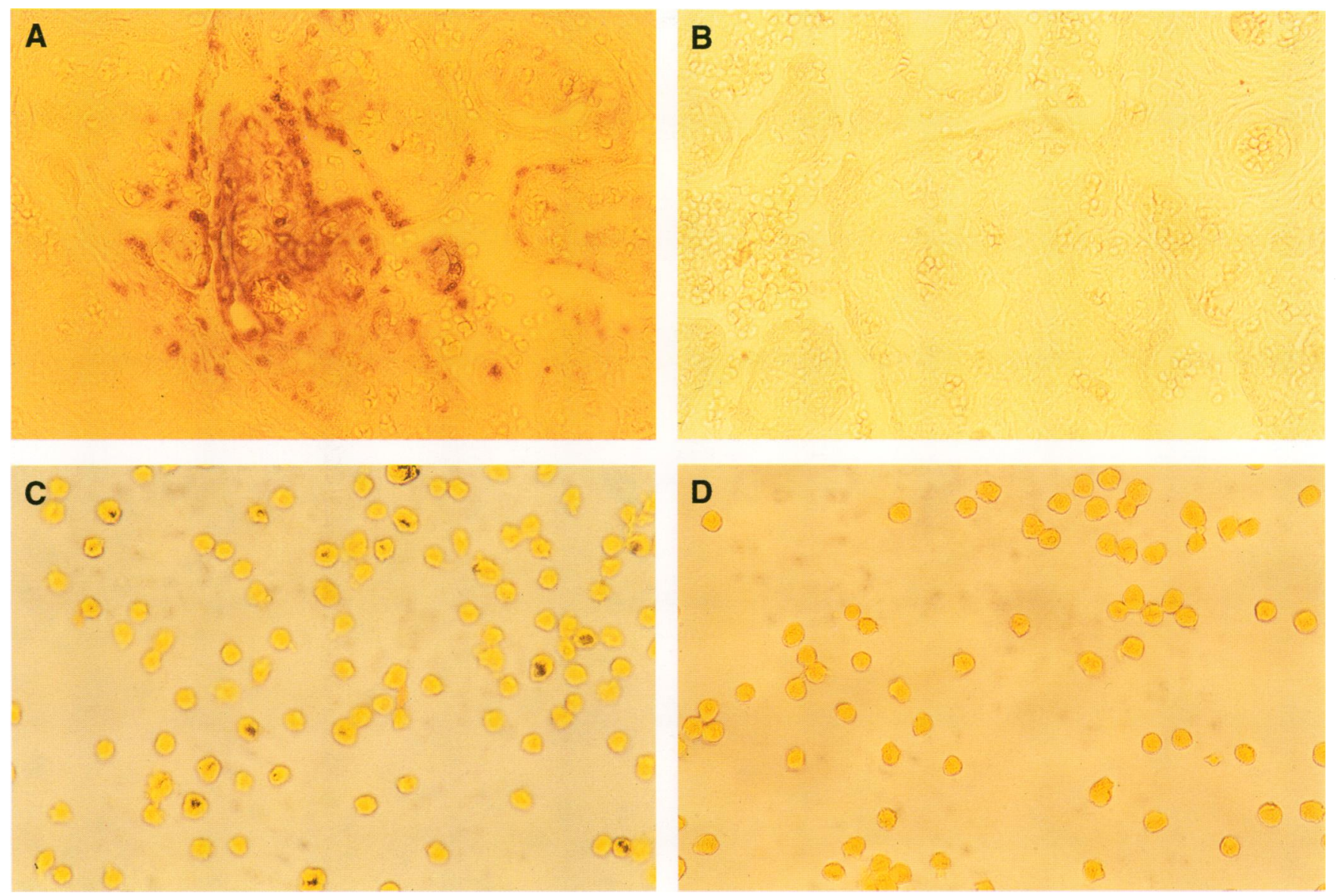

Figure 1 In situ hybridisation of placental tissue and controls. (A) Hybridisation of chlamydial DNA in human placenta with the Chlamydia trachomatis plasmid DNA derived, dUTP labelled RNA probe. (B) No hybridisation in the same placental tissue with the vector ( $p G E M-3 Z f(-))$ DNA derived, dUTP labelled RNA probe (negative control). (C) Hybridisation of chlamydial DNA in McCoy cell culture with the C trachomatis probe. (D) No hybridisation with the vector probe in infected McCoy cells (negative control).

POLYMERASE CHAIN REACTION AMPLIFICATION The oligonucleotide primers (KL1, 5'TCCGGAGCGAGTTACGAAGA-3'; KL2, 5'-AATCAATGCCCGGGATTGGT-3') were used to amplify $C$ trachomatis plasmid DNA. We also used $\beta$ globin primers PC03, PCO4 (5'-ACACAACTGTGTTCACTAGC-3'; 5'CAACTTCATCCACGTTCACC-3') to monitor sample preparations for the presence of possible inhibitors. Sections of paraffin wax embedded placental tissue were cut at $4 \mu \mathrm{m}$ and placed into sterile tubes. The tissue sections were deparaffinised with xylene and digested with proteinase $\mathrm{K}(1 \mathrm{mg} / \mathrm{ml}$ ) (Boehringer Mannheim) in lysis buffer $(50 \mathrm{mM}$ Tris $\mathrm{HCl}$, pH 7.5, $1 \mathrm{mM}$ EDTA, $1 \%$ Tween 20) at $37^{\circ} \mathrm{C}$ overnight. The reaction was stopped by heating to $95^{\circ} \mathrm{C}$ for eight minutes. After phenol and chloroform extraction the samples were precipitated with ethanol. Amplification was performed in $100 \mu$ reaction mixes for KL1-KL2 (200 $\mu \mathrm{m}$ dNTPs (Pharmacia, Uppsala, Sweden), $1 \mu \mathrm{M}$ each primer, $2 \mathrm{U}$ Taq polymerase, $10 \times$ polymerase chain reaction (PCR) buffer (Perkin Elmer, Norwalk, Connecticut, USA)) and for PCO3-PCO4 (200 $\mu \mathrm{M}$ dNTPs, $1 \mu \mathrm{M}$ each primer, $2 \mathrm{U}$ Taq polymerase, $1.5 \mathrm{mM} \mathrm{MgCl}, 10 \times$ PCR buffer without $\mathrm{MgCl}_{2}$ ), each containing $10 \mu \mathrm{l}$ of the sample. The reaction mixtures were heated to $95^{\circ} \mathrm{C}$ for five minutes and then subjected to 35 cycles of $95^{\circ} \mathrm{C}$ for one minute, $55^{\circ} \mathrm{C}$ for one minute, and $72^{\circ} \mathrm{C}$ for two minutes; a final extension was carried out at $72^{\circ} \mathrm{C}$ for $10 \mathrm{~min}$ utes. The amplification reaction mixture $(10 \mu \mathrm{l})$ was analysed by gel electrophoresis. ${ }^{7}$

\section{IMMUNOHISTOCHEMICAL STAINING}

APAAP staining of chlamydial inclusions in tissues was carried out using a modification of the procedure described by Mahony et al. ${ }^{8} \mathrm{~A}$ genus specific mouse monoclonal antibody recognising chlamydial lipopolysaccharide (Biokit, Barcelona, Spain) was used. To control for non-specific staining, duplicate tissue sections were incubated with mouse ascites fluid. The sections were examined by light microscopy.

\section{OTHER TESTS}

A routine microscopic histopathological study was performed using formalin fixed paraffin embedded tissue cut at $3 \mu \mathrm{m}$ and stained with haematoxylin and eosin. Microimmunofluorescence tests for the detection of the specific antibodies were performed using the antigens of $C$ trachomatis immunotype pools CJHI, GFK, and BED (Washington Research Foundation, Seattle), $C$ pneumoniae strain TWAR (Washington Research Foundation), and $C$ psittaci OA and 6 BC (Slovak Academy of Sciences, Bratislava, Slovakia). Antibodies to 16 microbes were determined from maternal serum samples using enzyme immunoassay. PCR assays were performed in the paraffin embedded tissue sections using primers from the DNA polymerase gene for HSV-1, HSV-2, 

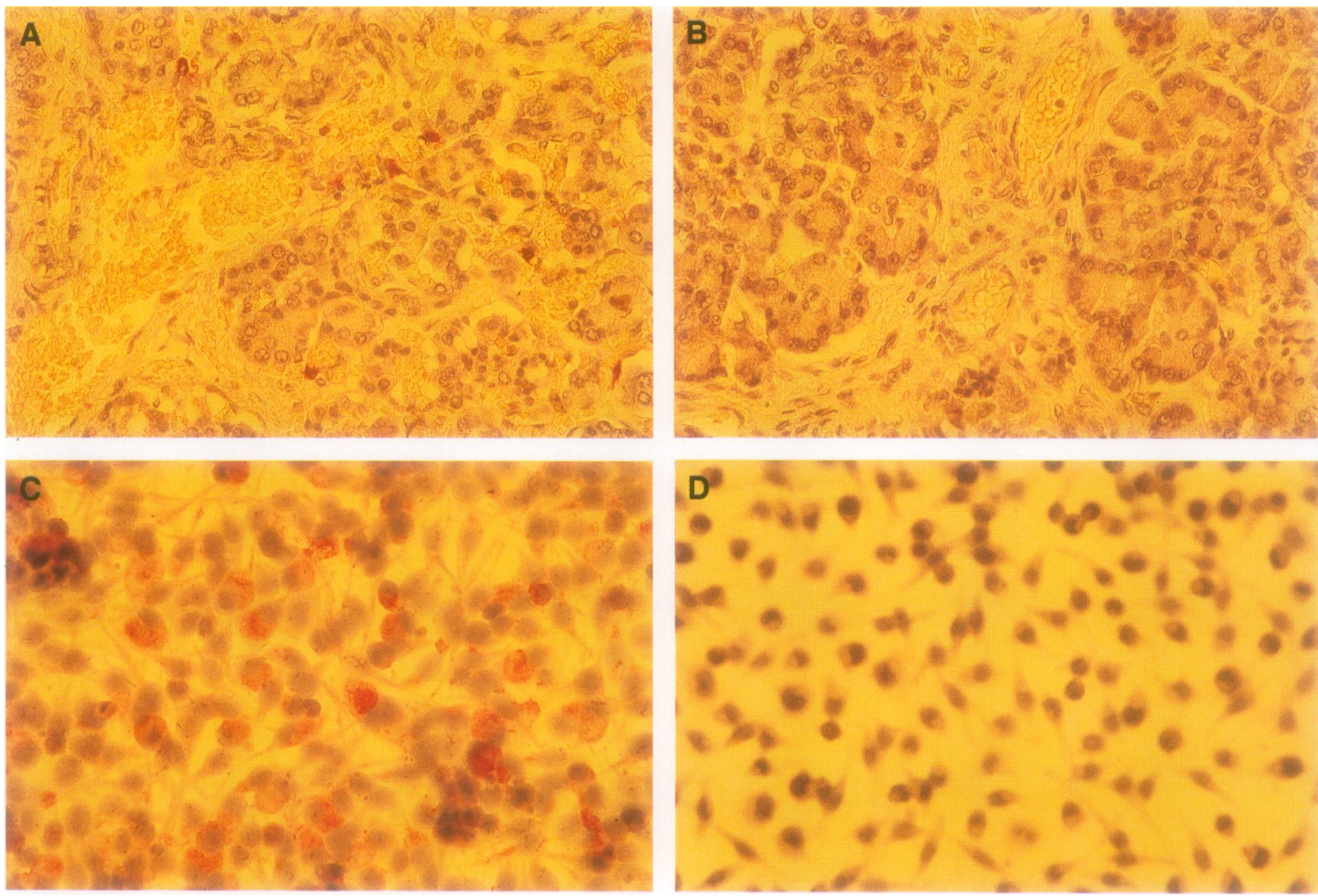

Figure 2 Immunoenzymatic APAAP staining of placental tissue and controls. (A) Detection of chlamydial antigen in placental tissue using a genus specific monoclonal antibody. (B) No staining is seen in a parallel section from the same tissue stained with normal mouse ascitic fluid. (C) Chlamydia trachomatis inclusions in McCoy cell culture are detected by APAAP staining using a genus specific monoclonal antibody. (D) Negative control (uninfected McCoy cells).

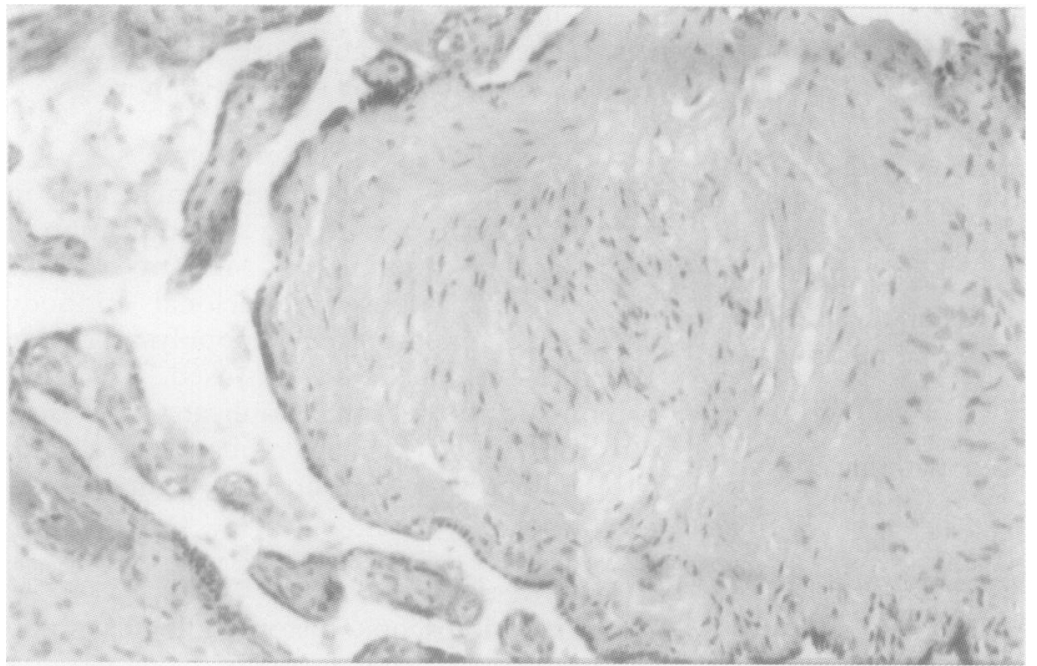

Figure 3 Routine histological examination of placental tissue shows very little, non-specific degenerative changes such as knotting of the syncytiotrophoblasts, small intervillous thrombus, and patchy necrosis. There is no inflammatory reaction. (Haematoxylin and eosin, original magnification $\times 160$.)

and varicella zosta virus and detected with luminometric microplate hybridisation. ${ }^{9}$ For Toxoplasma gondii PCR, the primers from the BI gene were used. In all PCRs, the paraffin embedded tissue sections were deparaffinised with xylene and digested by proteinase $\mathrm{K}$ as described for $C$ trachomatis PCR.

\section{Results}

$C$ trachomatis DNA and antigen were detected by in situ hybridisation and APAAP staining in placental tissue from the fetus. Criteria for positive hybridisation were adopted from studies with infected and uninfected McCoy cells (fig 1).

Cytoplasmic chlamydial inclusions were clearly identifiable with APAAP staining. The inclusions appeared bright red and granular against a background of blue nuclei (fig 2).

Routine histological examination revealed no specific signs of chlamydial infection (fig 3). In the PCR test for $C$ trachomatis, the placental tissue remained negative while $\beta$ globin gave a strong and specific band on gel electrophoresis indicating the reliability of the test. PCR tests for HSV-1, HSV-2, varicella zoster virus, and Toxoplasma gondii gave negative results for the placental tissue sections.

\section{Discussion}

To our knowledge this is the first case in which $C$ trachomatis has been identified in the human placenta. Presence of the organism has been suspected but evidence has been either serological or hypothetical. ${ }^{10}{ }^{11}$ The presence of $C$ trachomatis in the placenta represents a potentially significant threat to the fetus. Infection of the placenta will directly expose the fetus to an infection against which a specific therapy is available. $C$ trachomatis has been detected in fetal lung in a stillbirth case ${ }^{5}$ although the route of invasion was unknown. $C$ trachomatis has also been detected in endometrium and tubal tissue. $^{2}$ 
$C$ psittaci is known to cause abortions in sheep and it can be transmitted to humans. ${ }^{12}{ }^{13}$ In the present case, because only paraffin embedded blocks were available, chlamydial culture from placental tissue was not attempted. The in situ hybridisation and APAAP studies provide evidence to suggest that nucleic acid and antigen were present. Tests for other microbes were consistently negative. The failure of PCR to detect $C$ trachomatis may be explained by the amount of inhibitory material present in tissues. By our PCR test, $\beta$ globin was identified, but its concentration is higher than that of $C$ trachomatis nucleic acid. Using the same technique we have been able to identify the nucleic acid from other specimens.

Routine histological staining showed only non-specific degenerative changes. These changes were not suggestive of an ongoing infection.

$C$ trachomatis grows well in trophoblasts in vitro, ${ }^{14}$ as well as in amniotic cells. ${ }^{15}$ Chlamydial infections may cause necrosis as does C.psittaci in animal tissues. ${ }^{16}$ Thus, the presence of $C \mathrm{tra}$ chomatis in the placenta seems conceivable and, consequently, raises important questions regarding complications in pregnancy. Because $C$ trachomatis has been recognised as an increasingly prevalent and important genital infection, recommendations for screening have been reported, and it has been included in the antenatal care guidelines, at least in Germany. ${ }^{17}$

The complications of pregnancy associated with chlamydial infections have often been attributed to induction of heat shock protein, hypersensitivity, a lymphoproliferative reaction, or an autoimmune process. ${ }^{18}$ However, the presence of $C$ trachomatis in the placenta alters the potential impact of the infection as a cause of fetal complications and the consequent value of antimicrobial agents in such cases. In a large controlled trial, a seven day course of doxycycline and a single, $1 \mathrm{~g}$ dose of azithromycin were equally effective. ${ }^{19}$ During pregnancy, azithromycin is a valid treatment option for patients who cannot tolerate erythromycin ${ }^{20}$ and it has been raised to the first line therapies of infections caused by $C$ trachomatis. There are reports of improved pregnancy outcome after successful antibiotic therapy in cases where $C$ trachomatis has been identified in cervical specimens. ${ }^{21}$

$C$ trachomatis is one of the major causes of infections affecting mankind; several hundred millions of individuals are infected worldwide and, consequently, the number of fetuses exposed to chlamydial infection and associated complications may be high. The infection, once aquired, tends to persist and is usually symptom free. ${ }^{22}$ Awareness of $C$ trachomatis infections may improve both the diagnostics, by screening for $C$ trachomatis asymptomatic infections, and the therapy of these infections, and result in a better outcome for exposed children.

We acknowledge Ms Veronica W Alexander, Satu Cankar, and Mirjam Heljanne for expert technical assistance. The authors thank Dr Graham Cleator, Department of Pathological Sciences, University of Manchester for valuable comments and language revision of the manuscript. The work was supported by by a grant from the Helsinki University Central Hospita Research Funds, the Medical Research Council of the Academy of Finland, and Pfizer International Inc. Graham Cleator and MK are members of The European Union Concerted Action on
Virus Meningitis and Encephalitis.

1 WHO, Guidelines for the prevention of genital chlamydial infections. World Health Organisation, Regional Office for Europe, 1990.

2 Lan J, Van Der Brule AJ, Hemrika DJ, Risse EK, Walbroomers JM, Schipper ME, et al. Chlamydia trachomatis and ectopic pregnancy: retrospective analysis of salpingectomy specimens, endometrial biopsies, and cervical smears. F Clin Pathol 1995;48;815-19.

3 Donders GG, Moerman P, De-Wet GH, Hooft P, Goubau P. The association between Chlamydia cervicitis and neonatal complications. Arch Gynecol Obstet 1991;249:7985

4 Gencay M, Koskiniemi M, Saikku P, Puolakkainen M, Koskela P, Vaheri A. C. trachomatis seropositivity during pregnancy is associated with perinatal complications. Clin pregnancy is associated wis 1995;21:424-6.

5 Thorp JM, Katz VL, Fowler LJ, Kurtzman JT, Bowes WA Fetal death from chlamydial infection across intact amniotic membranes. Am f Obstet Gynecol 1989;161:1245-

6 Hyypiä T, Larsen SH, Ståhlberg T, Terho P. Analysis and detection of chlamydial DNA. $\mathcal{F}$ Gen Microbiol 1984;130 3159-64.

7 Mahony JB, Luinstra KE, Sellors JW, Chernesky MA. Comparison of plasmid- and chromosome-based polymerase chain reaction assays for detecting Chlamydia trachomatis nucleic acids. F Clin Microbiol 1993;31:1753-8.

8 Mahony JB, Sellors J, Chernesky MA. Detection of Chlamydial inclusions in cell culture or biopsy tissue by alkaline phosphatase-anti-alkaline phosphatase staining. 7 Clin Microbiol 1987;25:1864-7.

9 Koskiniemi M, Mannonen L, Kallio A, Vaheri A. Luminometric microplate hybridization for detection of varicellazoster virus PCR product from cerobrospinal fluid. $\mathcal{F}$ Virol Methods 1997;63:71-9.

10 Wilt JC, Wilt PC, Kordova N, Martin C. The human placenta as a possible reservoir of chlamydial infection in Northern Canada. Can ₹ Public Health 1976;67:114-16.

11 Koskiniemi $M$, Ämmälä $P$, Närvänen A, Saikku $P$ Söderlund $M$, Koskela $P$, et al. Stillbirths and maternal Soderlund $M$, Koskela $P$, et al. Stillbirths and maternal serology. Acta Obstet Gynecol Scand 1996;75:657-61.

12 Beer RJS, Bradford WP, Chart RJC. Pregnancy complicated by psittacosis acquired from sheep. $B M \mathcal{F} 1982 ; 284: 1156-7$.

13 Roberts W, Grist NR, Giroud P. Human abortion associate with infection by ovine abortion agent. $B M F$ 1967;4:37.

14 Banks J, Glass R, Spindle AI, Schachter J. Chlamydia trachomatis infection of mouse trophoblast. Infect Immun 1982;38:368-70.

15 Harrison HR, Riggin RT. Infection of untreated primary hurrison HR, Riggin RT. Infection of untreated primary human amnion monolayers

16 Storz J. Chlamydia and Chlamydia-induced diseases. Springfield: Charles Thomas Publishers, 1971.

17 Dieterle S. Chlamydieninfektionen in Gynakologie und Geburtshilfe. Geburtshilfe-Frauenheil 1995;55:510-17.

18 Witkin SS, Jeremias J, Toth M, Ledger WJ. Proliferative response to conserved epitopes of the Chlamydia trachomatis and human 60 -kilodalton heat-shock protein by lymphocytes from women with salpingitis. Am $\mathscr{f}$ Obstet Gynecol 1994;171:455-60.

19 Martin DH, Mroczkowski TF, Dalu ZA, McCarty J, Jones $\mathrm{RB}$, Hopkins SJ, et al. A controlled trial of a single dose of azithromycin for the treatment of chlamydial urethritis and cervicitis. N Engl f Med 1992;327:921-5.

20 Bush MR, Rosa C. Azithromycin and erythromycin in the treatment of cervical chlamydial infection during pregnancy. Obstet Gynecol 1994;84:61-3.

21 Cohen I, Veille JC, Calkins BM. Improved pregnancy outcome following successful treatment of chlamydial infection. $\mathcal{F A M A}$ 1990;263:3160-3.

22 Beatty WL, Morrison RP, Byrne GI. Immunoelectronmicroscopic quantitation of differential levels of chlamydial proteins in cell culture model of persistent Chlamydia traproteins in cell culture model of persistent Chlamydian 